\title{
URBAN METABOLISM AS AN APPROACH TO ACHIEVE RESOURCE EFFICIENT COMMUNITIES: A CASE STUDY OF AL SHAKHLOBA, BURULLUS LAKE, KAFR EL SHEIKH, EGYPT
}

\author{
ALSHAIMAA ELABASY \& MOHAMED IBRAHIM \\ Department of Architecture, Faculty of Engineering, Alexandria University, Egypt
}

\begin{abstract}
Efficient use of natural resources has become increasingly important due to the pressure resulting from population growth, increased demand for resources, and globally unprecedented waste generation habits. Therefore, exploring the flows of urban resources (i.e. water, energy, land and materials) could help one to reach a better understanding of the complex processes of entry and exit of such resources. This study analyzes the inflows and outflows of one of the resources - namely energy - within the Egyptian community "Al Shakhloba village". This study aims to formulate a model that simulates and optimizes the resources flows in communities by means of the urban metabolism approach; study human interaction with energy use in one of the small Egyptian communities through the use of interview questionnaire; and identify the current state for the energy flow. The main conclusions and recommendations of this case study can improve energy resources management in Shakhloba village, in order to convey a vision to decision-makers about how to manage energy resources within the scope of achieving sustainable development. In addition, it shall contribute to sustaining a more efficient use of energy resources.

Keywords: urban metabolism, energy, energy consumption, energy efficiency, resource efficiency, Shakhloba village, Egypt.
\end{abstract}

\section{INTRODUCTION}

Recently, enormous amounts of resources are being consumed within human settlements and their physical impact on the natural environment, such as urban and rural sprawl, housing demand, transportation and basic infrastructure, is rapidly increasing. Thus, the need for efficient management of resources to reduce societal environmental impacts, in parallel with applying the objectives of sustainable development, is crucial in addition to incorporating the concept of resource management within the stage of urban and rural design into especially marginalized productive communities. The main characteristics of communities are the consumption of large quantities of natural resources and the production of larger amounts of waste and pollution, throughout the life of these projects [1]. However, the currently adopted pattern of their use shall deplete the resources, causing such natural resources to be scarce. In addition, this shall contribute to the degradation of ecosystems, and make the prices of natural resources increasingly fluctuating. The ultimate test would be to achieve an optimum balance between delivering greater value and more services and using fewer resources [2]. Recently, several concepts and terms have emerged that have often preoccupied the world around the concept of environment and sustainability, thus the concept of urban metabolism has been brought to light.

The concept of 'Urban Metabolism' (the flow of resources - i.e., materials and energy through a community) can be used to outline the notion of how to improve citizens' access to essential services (a focus on collective well-being), while managing their resources rationally, and producing minimum or recyclable waste. Urban metabolisms must shift from 'linear' to 'circular', which necessitates integrating new methods of managing the flow of 
resources within the community. This concept must be adopted to assist strategic planning at local government level. Local governments should quantify communities' inputs (e.g., energy, biomass) and outputs (e.g., waste and emissions), and use such data to develop resources efficiency strategies [3]. Urban Metabolism has promoted quantitative approaches to urban and rural resource flows assessment and served as an inspiration for bright design ideas for sustainable communities [4], [5], consequently, allowing for the identification of leverage points for resource-efficiency interventions. This concept has been widely applied to various disciplines in order to assess cities' sustainability in relation to resource consumption and waste generation. The idea that urban environments are similar to metabolic systems has given rise to the reconsideration of how environmental, social, and economic factors intertwine to shape urban phenomena [3].

\section{URBAN METABOLISM APPROACH}

In order to explain the concept of urban metabolism, we have to define the concept of metabolism itself. Metabolism is the sum total of the chemical processes that occur in living organisms, resulting in growth, production of energy, elimination of waste material, etc. [6]. For instance, one's metabolism is the way through which the chemical processes in one's body use food efficiently to generate new cells and provide you with energy.

\subsection{Definition of urban metabolism}

The concept of Urban Metabolism has re-emerged after being overlooked for many years, due to the growing population and the importance of conserving natural resources. Interestingly, there is no consensus in the literature on the foundations of the concept. For instance, Kennedy et al. [7], Wolman [8], Marx [9, p. 556], Odum et al. [9, p. 555] (Table 1) give different definitions of urban metabolism.

Table 1: Different definitions of urban metabolism. (Source: The authors.)

\begin{tabular}{|l|l|}
\hline Authors and year & Definitions \\
\hline $\begin{array}{l}\text { Agricultural chemists } \\
\text { (19th century) }\end{array}$ & $\begin{array}{l}\text { Understanding the cycle of organic matter and nutrients and fertilizer } \\
{[10] .}\end{array}$ \\
\hline Karl Marx (1883) & $\begin{array}{l}\text { Describing the exchange of materials and energy between society and } \\
\text { nature [3]. }\end{array}$ \\
\hline Abel Wolman (1965) & $\begin{array}{l}\text { Process of supplying material, energy and food to a hypothetical city [8]. } \\
\text { Wolman published the first explicit application of the metabolism } \\
\text { concept to the urban sphere. }\end{array}$ \\
\hline Odum (1970) & Conceptualization of energy flow [9]. \\
\hline $\begin{array}{l}\text { Fischer-Kowalski and } \\
\text { Walter Hüttler (1999) }\end{array}$ & $\begin{array}{l}\text { Sum of Material and Energetic Inputs = Sum of Outputs + Changes in } \\
\text { Stock [11]. }\end{array}$ \\
\hline Huang \& Hsu (2003) & $\begin{array}{l}\text { Process of transforming all the materials and commodities for sustaining } \\
\text { the city's economic activity [12]. }\end{array}$ \\
\hline Kennedy et al. (2007) & $\begin{array}{l}\text { Collection of complex sociotechnical and socio-ecological processes by } \\
\text { which flows of materials, energy, people, and information shape the city, } \\
\text { service the needs of its populace, and impact the surrounding hinterland } \\
\text { [7]. }\end{array}$ \\
\hline
\end{tabular}

Taking into account the bio-based metaphor "metabolism", a community bears resemblance to an organism in terms of intaking, digesting, and releasing materials while exchanging energy with the external environment [13]. Wolman was the first to describe a community as an organism with metabolic processes [8]. Gradel (1999) also adopted the 
same concept stating that communities are analogous to organisms [14]. Thereby, examining the metabolic flows of communities enables us to consider the rates at which resources are being depleted and wastes are being produced. As for Built Environment, the metabolic flows represent raw materials, energy and water which are transformed into building stocks with an outflow of waste energy and water [8]. On the one hand, urban metabolism is based on an analogy of an organism's metabolism with inputs and outputs [15]. A community is highly intricate if compared to a single organism, whereas each system element can be viewed individually with inflows and outflows. Then these individual elements can be overlaid with one another more congruently as an ecosystem [16]. Urban metabolism can be defined as a model to facilitate how to describe and analyze the flows of materials, energy, people, and information shape within cities. It offers a metaphorical framework within which we can study how natural and human systems interact.

\subsection{Urban metabolism framework}

The current city metabolism configuration, which is mostly linear, can be represented by the organism metaphor. Cities obtain the majority of their materials (such as biomass, water, construction material and energy requirements) from the sparsely inhabited rural areas, yet such materials are not efficiently utilized. The disposable waste can be in any form solid, liquid or gaseous. Thus, the current linear metabolism makes the cities vulnerable, owing to their dependency on the resources, which burdens the local resource supplies and adversely impacts the natural environment during the processes of resource extraction and waste disposal. On the contrary, an ecosystem metaphor of cities represents resource efficiency and closed loops in which all outputs are potential inputs, thus offering a stronger prospect for achieving urban sustainability. A circular metabolism is quite similar to a natural ecosystem with efficient consumption, recycling and reuse of resource flows. Urban metabolisms are facing a complicated challenge, namely shifting from linear to circular perspective, where waste can be used as a resource [3]. The processes needed to flow resources within communities are affected by the human element, its consumption, behavior and various activities, in different sectors such as housing/services/transportation, etc. The human-related elements affect gaseous emissions, and liquid and solid waste, and this gives an indication of resource efficiency. Fig. 1 shows a proposed model for resources efficiency.

\section{ENERGY EFFICIENT COMMUNITIES}

The potential to reduce urban flows is governed by many factors, including but not limited to: urban management and planning, compactness, urban morphology and urban form (Fig. 2). The aforementioned factors shall significantly establish the Resource Use Pattern. These factors not only determine the way the population moves and lives, but also define the need for maintenance (particularly, buildings and roads deterioration rate, and the quality of and way in which services are provided). Poorly planned cities can cause constant waste of resources [17].

\subsection{Energy situation in Egypt}

Egypt is a highly rich country in terms of natural resources. The country's natural resources include: Natural gas, oil, coal, precious stones, and massive reserves of fossil energy sources. Egypt's reserves are estimated to be about 4,189 billion barrels of oil and approximately 77,200 billion cubic meters of natural gas, as the reserves are in the form of both mainland and coastal deposits [18]. Over $90 \%$ of the Egyptian electricity is generated exclusively from 


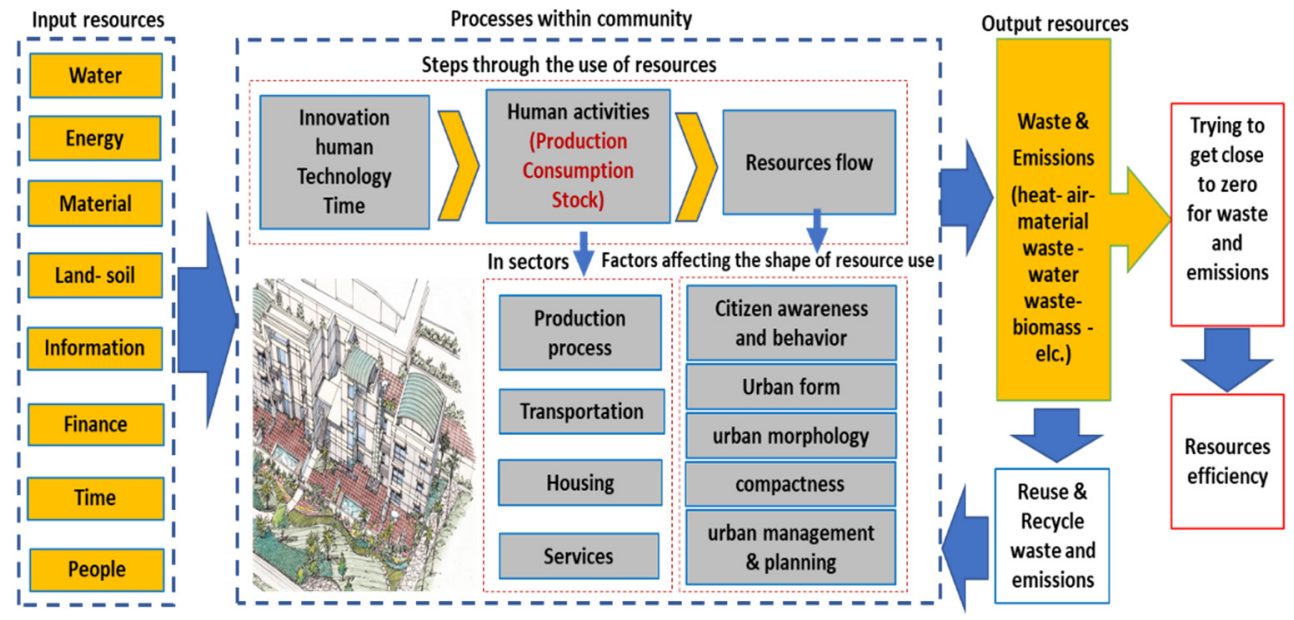

Figure 1: Urban metabolism model to resources efficiency.

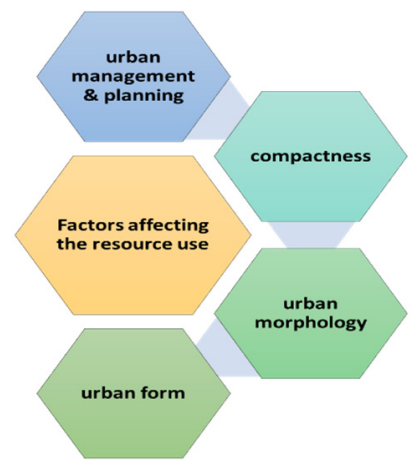

Figure 2: Factors affecting resource use.

oil and natural gas. Meanwhile, the major obstacle that Egypt faces, especially in the energy sector, is the increasing population growth rate, which is estimated to be $1.3 \%$ annually, which means increasingly higher demand, which shall eventually expedite the rate of depleting the country's major resources [19].

From both energy and environmental perspective, it is crucial to use biomass as a renewable source of energy. Using the biomass can reduce the increasing depletion rate of fossil fuel, resulting from the rapid increase in energy consumption (Fig. 3). The following are the four main types of biomass energy: Agricultural residues (dedicated bioenergy crop residues), municipal solid wastes, animal wastes, and sewage sludge. The computed potential biomass quantity and its theoretical energy content were based on statistical reports, literature reviews, and personal investigations. The results show that Egypt produces a considerable amount of biomass, whereas the total theoretical energy content is estimated to be $416.9 \times 10^{15} \mathrm{~J}$. The dry biomass produced from bioenergy crop residue sources has been estimated at about 12.33 million tons/year, of which $63.75 \%$ is produced from rice straw. This source represents the highest percentage (44.6\%) among the total theoretical potential 
energy in Egypt, followed by municipal solid wastes, which could produce up to $41.7 \%$ (corresponding to the annual amount of 34.6 million tons). Meanwhile, the remaining theoretical potential energy could be produced from animal and sewage wastes. The estimated biomass with its considerable potential energy content represents an important renewable energy source in Egypt [21].

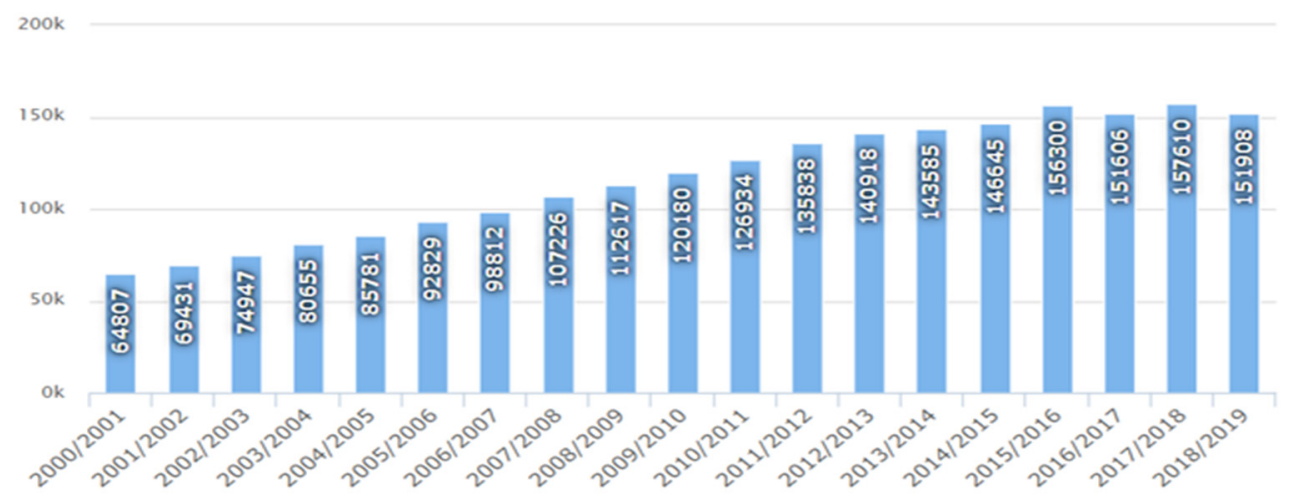

Figure 3: Total energy consumed (million KW/h) [20].

\section{METHOD AND PROCEDURES}

Concerning resource management policy, there is little or no information about the actual consumption of different energy resources. Thus, in order to address this current gap in identifying how different communities perform regarding energy resource consumption patterns and respective intervention priorities, the study strongly focuses on in-depth discussions with stakeholders (including residents, civil organizations, users and local municipality) and household/parcel audits to account for energy resource flows on the demand side. Furthermore, the study tracked the energy resource flows from source to sink, investigating the upstream and downstream processes. The research depends on an interview questionnaire of inhabitants for data gathering. Since the interviews require a great amount of time and effort and due to the conditions created by the Corona virus, in addition to the fact that the researched society is homogeneous, the researcher took an available sample of $5 \%$ of the researched society, that is, about 77 buildings/parcel, out of the total researched community of 1,536 buildings/parcel. The heads of households of these buildings were interviewed to collect data after testing the research tool. Some descriptive statistics coefficients (frequencies/percentages/arithmetic means/standard deviations) and inferential statistics (Spearman's correlation coefficient) were used.

First, the fishing community, its nature, characteristics, diverse resources, characteristics of the inhabitants and their daily activities, were identified through research and observation, in addition to interviews with some of the fishermen and the leader of fishermen for the area. Second, various issues, energy resources, and potentials on the ground were identified through transect walks. Third, different archetypes (to cover all existing land uses) were identified using GIS maps of land use, building heights, building conditions, and construction materials and knowing all processes within the community. Hence choosing sample parcels (buildings) for identifying energy resource flows. Fourth, within the sample parcels, demand of the investigated energy resource at the household/unit level was quantified and other related attributes of energy flows were documented using interview questionnaire; this was 
in addition to assessing waste (food/animals/birds/sewage sludge) output from buildings. Finally, a statistical analysis was carried out to obtain results for energy uses in the selected population.

\section{CASE STUDY (SHAKHLOBA VILLAGE)}

Despite the greater consumption of energy in cities, one of the fishing communities was selected as a case study for several reasons, including:

- Lack of a clear vision to manage the flow of energy resources in these communities to preserve them for future generations. Such communities are vulnerable due to their resource dependency on their current linear process, which imposes stresses on local resource supplies and negatively impacts the natural environment.

- Fishing communities are very important and have a potential to be turned into selfsustaining communities; they are characterized by energy consumption used for boats movement (fishing and transport of people), and the wide use of furnaces to grill fish in those areas. These areas are also characterized by various energy resources that are not visible to the community, such as the waste resulted from raising poultry and fish (Fig. 4). This can be converted into energy, making the village self-sufficient in energy consumption. These resources require more efficient management.

- These communities share a similar lifestyle (Fig. 5), the same function, and the same energy consumption and flows.

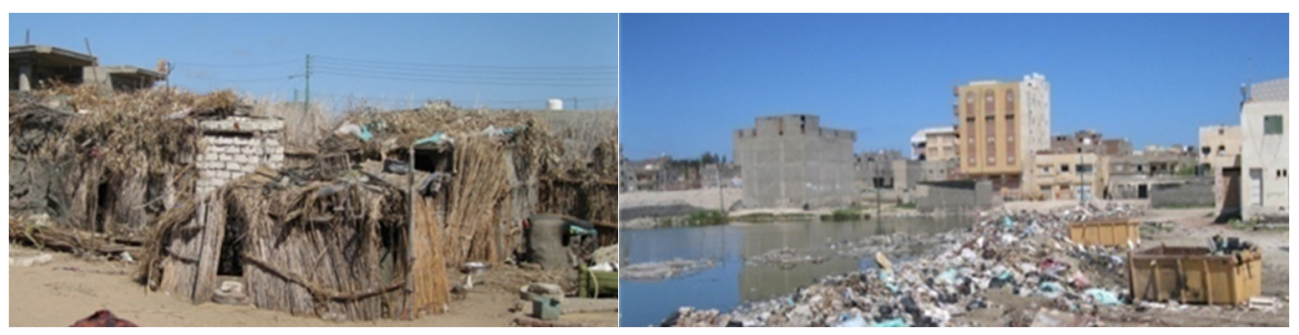

Figure 4: Showing negligence of existing resources in fishing communities.

\subsection{Case study: Shakhloba village}

The village is being one of its most exquisite spots located south of Lake Burullus. Its administrative subordination is the Sidi Salem Center, Kafr El Sheikh Governorate, Egypt (Fig. 6). Its total area is about 60 acres. The population of 17,000 comprises mostly fishermen and boat builders; the number of buildings is about 1,536 [22]. It is known among local travelers for its alluring landscapes, delicate ecosystem and migratory birds; it is considered a destination for tourism.

Shakhloba is directly overlooking the lake; it is located at the end of a small channel from the Nile that flows into Lake Burullus. The village has two entrances, one through land and the other one through the sea. It is divided into two parts, eastern and western mainlands, separated by a waterway and connected by bridges. The reason for the name of the village is due to the gathering of quantities of fish called "Shakhlout" that come from the Mediterranean Sea and stay in this place. The village is isolated due to its location from the rest of the villages, and therefore it has preserved its identity and traditions, as well as the 

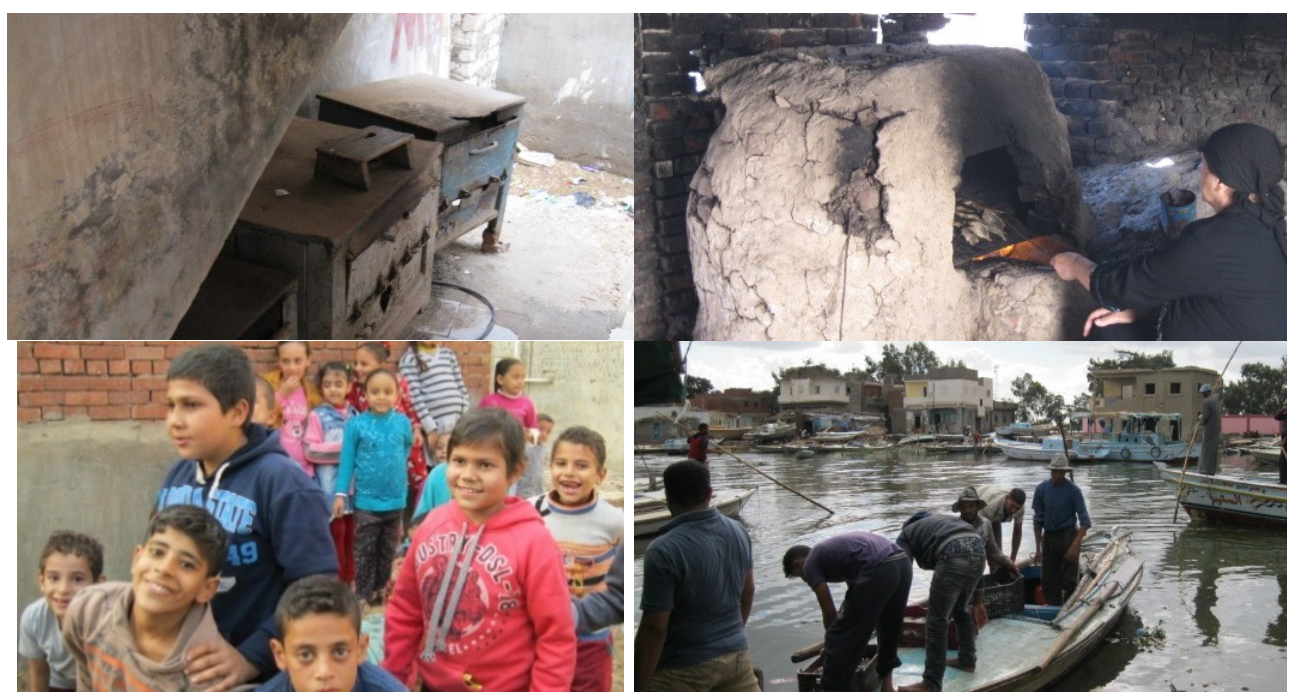

Figure 5: Life style in fishing communities in Egypt.
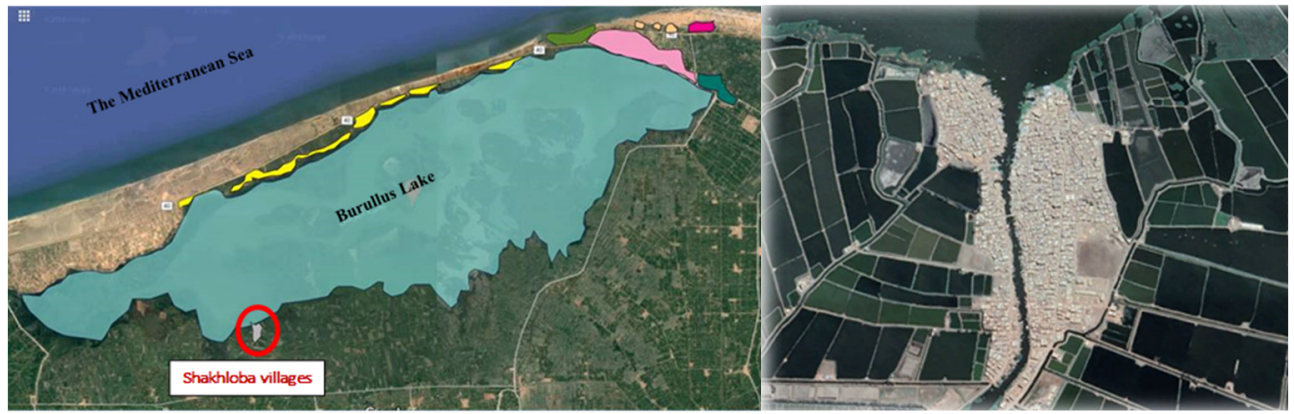

Figure 6: Location and layout of Shakhloba village. (Source: Google Earth, 2021.)

distinction of its inhabitants with the hospitality and welcoming visitors from all over the world, as it is considered a tourist attraction.

\subsection{Characteristics of Shakhloba village}

The architectural, social, economic and environmental aspects greatly affect energy consumption and flows within communities. Some of these aspects are explained below according to the field and statistical study.

\subsubsection{Social aspects}

The field and statistical study revealed the strong relationship between social factors, the behavior and needs of the population, and the flows of energy and biomass inside the village. It became clear that most of the village residents raise poultry inside buildings, whether on the roof, courtyards, or a separate room in the building. The percentage of the population that raises poultry is $83.1 \%$ of the total selected sample, but the waste produced by these birds is 
not exploited, so it turns out that $98.4 \%$ of those who keep poultry inside the residential units dump their waste in the Burullus lake and on the streets. As for food waste, they use it to feed their poultry, and residents who do not keep poultry dump food waste into the lake.

\subsubsection{Architecture aspects}

The identity of fishing communities and the shape of buildings has changed. Initially, the fisherman used local building materials in the wrong way, but he took into consideration his needs and the needs of the fishing profession. But when money was available to the fishermen, they began to change the housing units to make it more suitable for them. The residents' needs affected the design of residential buildings, regarding the change of building materials (from local materials to concrete buildings) to be able to raise the heights of the buildings into two to three floors, which affected the flows and energy consumption significantly. Figs 7 and 8 show the change of buildings and the design of residential buildings within the village.

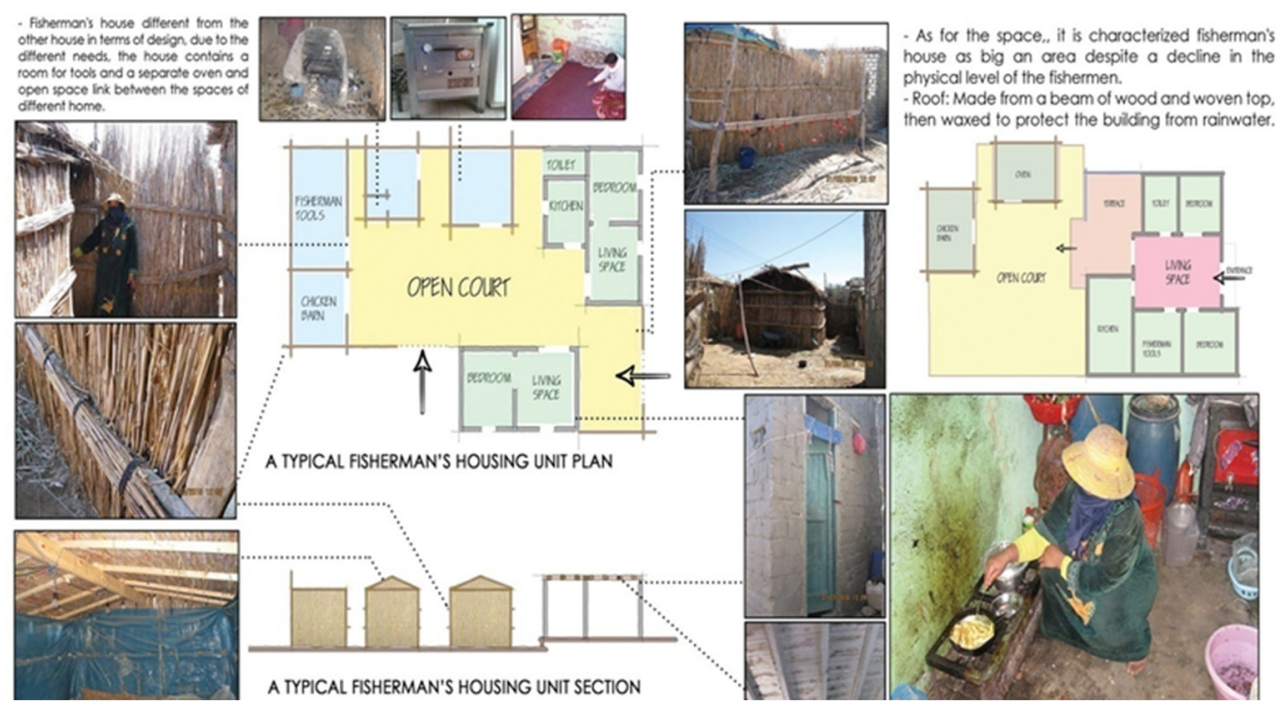

Figure 7: Old typical fisherman's housing.

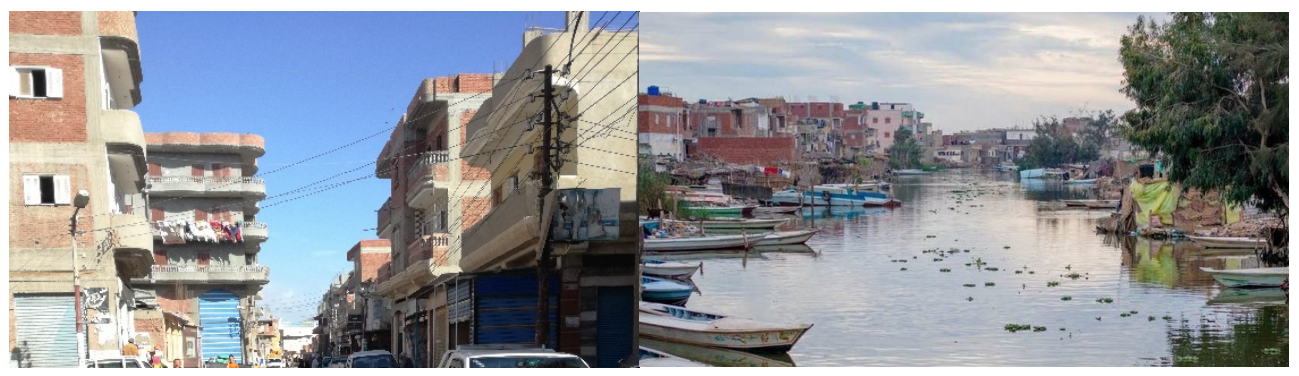

Figure 8: Current typical fisherman's housing. 


\subsubsection{Environmental aspects}

The lake includes a noteworthy number of environments, with swamps and sand plains prevailing, and constitutes an ideal habitat for 135 land and water plant species as well as an important stop-over point for migrating birds [23]. The lake is considered a wetland of international importance for birds, despite the simplicity of the village's nature. However, residents suffer from lake pollution and neglect. Agricultural drainage water accounts for $97 \%$ of the total inflow to the lake (3.9 billion $\mathrm{m}^{3}$ per year), followed by rain water $(2 \%)$ and groundwater (1\%). Sixteen percent of the lake's water evaporates and $84 \%$ flows into the sea. According to a biodiversity report by the Egyptian Environmental Affairs Agency, the lake is a natural habitat for 33 species of fish, 23 species of reptiles, 112 species of birds, and 18 species of mammals. Fish species in the lake have declined significantly since the beginning of the 20th century when 52 different species were recorded. This is mostly due to the inflow of agricultural drainage into the lake resulting in lower salinity [24].

\subsubsection{Economic aspects}

The economy in the village is based mainly on fishing. Fishing is the main source for life and income. This village is distinguished by its specialization in the craft of fishing. After fishing journey ends in the lake, the second stage comes, which is the stage of fishermen taking the fish they got during the day from boats to auction to sell. Where sellers exist from inside and outside the village. Other work that the fishermen depend on, making all types of fishing nets, various boats and scuttle.

\subsection{Results and discussion}

The energy resources in the village are classified into solar energy, wind, electricity, natural gas, biomass and petroleum, and the energy consumed in several sectors are shown in Table 2. The following is a study of the energy resources in the village through the official authorities and the field study of the village.

\subsubsection{Electricity}

Electricity is used in all sectors (residential, commercial, services, economic activities, transportation). The total electricity consumption per month is 509,482 kilowatts. Through the field study, it was also found that there are continuously power cuts in the village, especially in winter seasons.

\subsubsection{Natural gas}

Through the statistical study, it was found that the village fundamentally depends on gas due to the lifestyle and needs of its inhabitants. Fish grilling takes place continuously inside the village, as well as baking bread in the ovens. The average gas consumption per month for the buildings sample is about 5 cylinders, which is about 150 liters of gas per month for the building. The percentage of buildings with an oven is about $93.5 \%$ of the selected buildings.

\subsubsection{Biomass}

There is a variety of resources of biomass in the village, such as reeds, Nile rose plant and bird droppings on the lake. Locals harvest reeds and use them to make mats which are used for a variety of purposes in the nearby community [23]. The village also contains many bird, animal and food waste, which can be converted into energy to obtain gas. The average Egyptian food waste is $73 \mathrm{~kg}$ per year [25], so the food waste in the village must be about $103,416.7 \mathrm{~kg}$ per month, in addition to poultry droppings and sewage, which is drained into the lake because there is no sewage network. 
Table 2: Energy consumption within the village. (Source: Field Study \& North Delta Electricity Distribution Company \& leader of fishermen.)

\begin{tabular}{|c|c|c|c|}
\hline \multirow{2}{*}{$\begin{array}{l}\text { Resources of } \\
\text { energy }\end{array}$} & \multirow{2}{*}{ Sectors } & \multicolumn{2}{|c|}{ Energy consumption } \\
\hline & & Energy uses & Total consumption per month \\
\hline & \multirow{5}{*}{ Residential } & Lighting & \multirow{5}{*}{$\begin{array}{c}367,563 \mathrm{~kW} \text { of electricity }+ \\
230,400 \text { liters of gas }\end{array}$} \\
\hline & & Appliances & \\
\hline & & Cooking & \\
\hline & & Water heating & \\
\hline & & $\begin{array}{l}\text { Space heating \& } \\
\text { cooling }\end{array}$ & \\
\hline \multirow{3}{*}{$\begin{array}{l}\text { Solar } \\
\text { Wind }\end{array}$} & \multirow{3}{*}{ Commercial } & Lighting & \multirow{3}{*}{$46,969 \mathrm{~kW}$ of electricity } \\
\hline & & Appliances & \\
\hline & & $\begin{array}{l}\text { Space heating \& } \\
\text { cooling }\end{array}$ & \\
\hline \multirow{8}{*}{$\begin{array}{l}\text { Natural Gas } \\
\text { Biomass } \\
\text { Petroleum }\end{array}$} & \multirow{4}{*}{$\begin{array}{l}\text { Services } \\
\text { (Education/ } \\
\text { Administration/ } \\
\text { Health/ } \\
\text { Religious/ } \\
\text { Recreation) }\end{array}$} & Lighting & \multirow{4}{*}{$6,550 \mathrm{~kW}$ of electricity } \\
\hline & & Appliances & \\
\hline & & Water heating & \\
\hline & & $\begin{array}{l}\text { Space heating \& } \\
\text { cooling }\end{array}$ & \\
\hline & \multirow{2}{*}{$\begin{array}{l}\text { Economic } \\
\text { activities }\end{array}$} & Fishing & $\begin{array}{l}240,000 \text { liters of petrol }+ \\
27,000 \text { liters of diesel }\end{array}$ \\
\hline & & $\begin{array}{l}\text { Fish farms/Fish } \\
\text { auction area }\end{array}$ & $88,400 \mathrm{~kW}$ of electricity \\
\hline & \multirow{2}{*}{ Transportation } & $\begin{array}{l}\text { Maritime } \\
\text { transport }\end{array}$ & 900 liters of diesel \\
\hline & & Road transport & 810 liters of diesel \\
\hline & \multicolumn{2}{|c|}{ Total consumption } & $\begin{array}{l}509,482 \mathrm{~kW} \text { of electricity }+ \\
240,000 \text { liters of petrol }+ \\
259,110 \text { liters of diesel }\end{array}$ \\
\hline
\end{tabular}

Note: These statistics are without road electricity and diesel consumption of fish farms due to unavailability of data.

\subsubsection{Petroleum}

This village is also known by its high consumption of petroleum in many sectors (transportation, economic activities); the total diesel consumption in the village is about 271,110 liters per month, while the total consumption of gasoline in the village is about 240,000 liters per month. This is in addition to the consumption of gasoline used by private 
cars, where the percentage of those who own private cars is about $5 \%$ of the selected sample, and the total consumption of gasoline for personal cars is about 6,795.5 liters per month.

Through the field study and statistical analysis, it was found that:

- The results of the study showed that there was a positive relationship between the building area and the rate of electricity consumption (the value of Spearman's correlation coefficient $=0.350$ and significant at 0.01 ), also there was a direct relationship between the number of floors and the rate of consumption (where the value of the Spearman correlation coefficient $=0.440$ and significant when 0.01 ).

- It was found that issues related to resources and their use occupy an important aspect in the lives of the population, as $88.3 \%$ of the buildings sample suffer from electrical energy problems such as interruptions and high prices; $75.3 \%$ complain about problems related to lake pollution and the spread of waste, and $86.9 \%$ of the buildings sample suffer from the lack of a sewage network.

- The population has a desire to help manage resources better, as the percentage of approval for separating the waste and placing it in the designated places, if available, is about $100 \%$ of the heads of household sample. The sample agreed by $80.5 \%$ to use solar energy to obtain electricity, due to the high electricity prices at the present time with the low level of income.

\section{CONCLUSION}

This paper confirms that the urban metabolism approach can be used for a better management of resources within communities for sustainability. It also confirms taking into consideration the importance of the impact of human behavior and activities on improving resource flows to reduce emissions and waste within communities, which reduces the negative impact on the environment. Through the field study, it was found that there is increasing awareness of the population on the importance of good resource management and desire to achieve resource efficiency to improve their lives. Also, it turns out that there is enormous amount of untapped resources that can be converted into energy, for example, converting biomass from various wastes into energy used in buildings, in order to preserve the environment from pollution and emissions and turn output resources into input resources again within the community. The main recommendations lie in improving the management of energy resources in order to convey a vision to decision makers on how to manage energy resources within the scope of achieving sustainable development. Particular attention should be given to neglected small communities that do not have clear management of resources.

\section{REFERENCES}

[1] Abdel-Wahab, K. \& Rizko, N.J., Urban agriculture as one of the ecological applications of the regenerative city. Journal of Engineering, 23(9), pp. 64-81, 2017.

[2] European Commission, Communication from the Commission to the Council, the European Parliament, the European Economic, Social Committee, and the Committee of the Regions "Analysis associated with the Roadmap to a Resource Efficient Europe". (COM(2011) 571 final of 20 Sep., vol. 147, 2011.

[3] Musango, J.K., Currie, P. \& Robinson, B., Urban Metabolism for Resource Efficient Cities: From Theory to Implementation, UN Environment: Paris, 2017.

[4] Zhang, Y., Urban metabolism: A review of research methodologies. Environmental Pollution, 178, pp. 463-473, 2013.

[5] Broto, V.C., Allen, A. \& Rapoport, E., Interdisciplinary perspectives on urban metabolism. Journal of Industrial Ecology, 16(6), pp. 851-861, 2012. 
[6] Definitions: Metabolism. https://www.dictionary.com/browse/metabolism.

[7] Kennedy, C., Cuddihy, J. \& Engel-Yan, J., The changing metabolism of cities. Journal of Industrial Ecology, 11(2), pp. 43-59, 2007.

[8] Wolman, A., The metabolism of cities. Scientific American, 213(3), pp. 178-193, 1965.

[9] Dinarès M., Urban metabolism: A review of recent literature on the subject. (Metabolisme urbà: una revisió de la literatura recent sobre el tema.) Doc d'Anàlisi Geogràfica, 60(3), pp. 551-571, 2014.

[10] Barles, S., Society, energy and materials: the contribution of urban metabolism studies to sustainable urban development issues. Journal of Environmental Planning and Management, 53(4), pp. 439-455, 2010.

[11] Fischer-Kowalski, M. \& Hüttler, W., Society's metabolism: the intellectual history of materials flow analysis, part II, 1970-1998. Journal of Industrial Ecology, 2(4), pp. 107-136, 1999.

[12] Huang, S.L. \& Hsu, W.L., Materials flow analysis and energy evaluation of Taipei's urban construction. Landscape and Urban Planning, 63(2), pp. 61-74, 2003.

[13] Chen, S. \& Chen, B., Sustainable urban metabolism. Encyclopaedia of Environmental Management, CRC Press, pp. 1-8, 2015.

[14] Samaniego, H. \& Moses, M.E., Cities as organisms: Allometric scaling of urban road networks. J. Transp. Land Use, 1(1):21-39, 2008.

[15] Pincetl, S., Bunje, P. \& Holmes, T., An expanded urban metabolism method: Toward a systems approach for assessing urban energy processes and causes. Landscape and Urban Planning, 107(3), pp. 193-202, 2012.

[16] Kennedy, C., Pincetl, S. \& Bunje, P., The study of urban metabolism and its applications to urban planning and design. Environmental Pollution, 159(8-9), pp. 1965-1973, 2011.

[17] European Environment Agency, Urban sustainability issues - What is a resourceefficient city? EEA Technical Report No. 23, 2015.

[18] Obukhov, S. \& Ibrahim, A., Analysis of the energy potential of renewable energy sources Egypt. MATEC Web of Conferences, EDP Sciences, 141, pp. 6-9, 2017.

[19] Energypedia, Egypt Energy Situation - energypedia.info, 2019. https://energypedia.info/wiki/Egypt_Energy_Situation\#Energy_Data. Accessed on: 23 Aug. 2021.

[20] Ministry of Electricity and Energy, Total Energy Consumed, Egypt, 2020. http://www.moee.gov.eg/test_new/ST taka.aspx. Accessed on: 23 Aug. 2021.

[21] Said, N., El-Shatoury, S.A., Díaz, L.F. \& Zamorano, M., Quantitative appraisal of biomass resources and their energy potential in Egypt. Renewable and Sustainable Energy Reviews, 24, pp. 84-91, 2013.

[22] Ministry of Housing, Utilities and Urban Communities, General strategic plan for the village of Shakhlouba, Egypt, 2019.

[23] MedWet Culture/Wetland Site, Burullus Lake, Egypt, 2021. https://www.medwetculture.org/wetland_items/burullus/. Accessed on: 23 Aug. 2021.

[24] El-Wardani, L., Shakhloba Island: An untouched piece of paradise in the heart of Egypt, 2019. https://english.ahram.org.eg/NewsContent/8/27/337926/Travel/News/ Shakhloba-island-An-untouched-piece-of-paradise-in.aspx. Accessed on: 23 Aug. 2021.

[25] Egyptian Food Bank, Average food waste for an Egyptian person in a year, 2018. https://cutt.us/EGXP1. Accessed on: 23 Aug. 2021. 